\title{
Conflict and Ambiguity in the Role of the Academic Library Director
}

\begin{abstract}
For the academic library director there is a multitude of expectations derived from diverse and often conflicting individuals and groups with whom this individual is concerned. Utilizing the framework of role theory, this study describes and analyzes the role of the library director. Influencing factors are viewed in terms of the director's perceptions, with particular attention to the presence of conflict and ambiguity. Directors' perceptions regarding sources of role definition, relations with immediate superiors, and perceptions of role-related expectations within the academic community are discussed.
\end{abstract}

$\mathrm{O}_{\mathrm{r}}$

F PARTICULAR CONCERN to our profession in recent years has been the role of the academic library director. Many knowledgeable observers and experienced practitioners have addressed the long unresolved problems of a changing professional identity.

In "The University Library in Violent Transition," Ralph E. Ellsworth complained that "we don't know what a librarian is, what he's supposed to do, or how to educate him." 1 He then went on to present an awesome list of the roles the academic library administrator is expected to fill: "a fund-raiser, a campus politician, a learned man and a reader of books, an expert on electronics, and an expert in the science of management," not to mention "the small problem of keeping out of jail because the technology of photo-reproduction has gotten ahead of the copyright laws."

Truly then, the library director stands at the vortex of a whole multitude of roles. These myriad roles carry varied and often contradictory requirements. Thus the academic library director is

Susan A. Lee is librarian, Nichols College, Dudley, Massachusetts. caught in the middle, among conflicting groups, persons, and factions.

McAnally and Downs examined at length the changing role of directors of university libraries, and their discussion of the sources of pressure, "the president's office, the library staff, faculty and students," based on the actual experiences of practicing library administrators, is most insightful. ${ }^{2}$ Yet their concluding suggestions-"better planning, improved budgeting techniques, and the introduction of new organizational patterns,"-seem to go astray. Certainly timely and of practical value, these proposals digress from the more basic problem of role definition. They may suggest good solutions; but they are still incomplete because no management techniques, no matter how sophisticated, will ever satisfactorily encompass the role of the academic library administrator.

Picking up on this, Roger Horn sarcastically dismisses McAnally and Downs' "traditionally reasonable conclusions," equating their list of desirable qualities with the completeness of a god. ${ }^{3}$ Horn himself approaches this problem of the uncertain role of an academic library administrator more di- 
rectly. "Much, if not most of the trouble academic library managers suffer is related to their weak grasp of what they are or should be trying to be." The real problem, as Horn sees it, is lack of role definition. And the answer, according to Horn's logic, is the delineation of his personal idea of academic library management. Roger Horn will provide the necessary role definition, and all will be well in academia.

Alas, the complexity of this problem does not lend itself to such an easy or final solution. There is, of course, no single "idea" of academic library management. Rather the role of the academic library director is made up of a multitude of "ideas." Each of the sources of pressure (the president, staff, faculty, students, etc.) has its own "idea" of library management, making the library administrator a "fully-, even over-stretched individual, trying hard to combine personal, university, administrative and professional roles." 4 The complexity of this problem calls for further investigation and study. We cannot look for answers until we have studied the problem seriously.

Utilizing the framework of role theory, this paper examines the pressures that occur in academic library administration. The underlying premise of this study is that the common and distant goal-to make understandable the role of the library director-requires a systematic and conceptual approach. Toward this end, the work of Kahn and his associates (Organizational Behavior Program of the University of Michigan's Survey Research Center) has served as a model.

The work of the individual library administrator is seen as an array of roles which that person plays in the particular organization to which he or she belongs. The conceptual language used for the description and analysis comes from Kahn's work in industrial organizations. ${ }^{5}$ Associated with each office is a set of activities which are defined as potential behaviors. These activities constitute the role to be performed, at least approximately, by any person who occupies that office. Each office in an organization is related to certain others. These others are role senders. Role expectations for a certain office and its occupant exist in the minds of these role senders, thereby representing standards in terms of which they evaluate his or her performance.

It is hoped that this borrowing from the social sciences will allow us to move beyond the accumulation of miscellaneous data, external facts, and individual opinion.

\section{METHODOLOGY}

In order to inquire as thoroughly and specifically as possible into the library director's perceptions regarding sources of role definition, relations with an immediate superior as a key role sender, and perceptions of role-related expectations within the academic community, interviews were conducted with twenty academic library directors. This group is not intended to be representative for the purpose of quantifiable analyses, but rather as a means of exploring expectations, attitudes, relationships, and sources of conflict. The twenty libraries were selected from a standard college directory. Institutions included in the survey were chosen according to a total enrollment ranging from 2,000 to 21,000 . The twenty libraries selected represent four states (three New England states and New York) and include six public and fourteen private institutions.

An interview schedule was used to elicit and stimulate relevant information from the participating library directors. Individual visits were arranged with each director, and the questions were interpreted orally by the interviewer. The questions were, in the main, 
open-ended and frequently accompanied by probes to encourage exploration of new and promising lines of discussion.

\section{EXTERNAL INFLUENCES}

The library director's position is one for which many significant role senders are located in a different system (outside the college or university) or in another unit within the same organization (within the school but outside the library). Two dimensions were initially distinguished: the amount of time the library director spends in contact with people outside the library (including administrators, faculty, and students) and the perceived importance of such contacts to the librarian's effective performance of his or her work.

In responding to a question on the frequency of work-related contacts beyond the library, 15 percent of the directors answered "nearly all the time"; 60 percent answered "rather often"; 20 percent "sometimes"; and 5 percent "rarely."

Asked to rate the extent to which their performance depended on the behavior of people outside the library and with whom they were required to interact, 30 percent answered "to a very great extent"; 45 percent "to a considerable extent"; 15 percent "to some extent"; and 10 percent "very little."

The library director is thus faced with a sizable body of role senders whose demands are hard to predict and hard to control. These demands will be generated by the dynamics of other departments or organizations and will shift with the vicissitudes of those groups. Moreover, the demands are likely to be untempered by an adequate understanding of what these shifts will mean for the library director.

Support for the view that the directors are exposed to chronic conflict may be found from their estimates of the frequency with which their jobs placed them "in the middle" between two groups of people. In their estimates, 10 percent stated they experienced role conflict "nearly all the time"; 60 percent "rather often"; 25 percent "sometimes"; and 5 percent "rarely." This feeling of being "in the middle" seemed to increase with the amount of time the directors spend in relations with persons outside the library.

\section{DEMANDS AND Resources}

What are the groups which convey to the library director the sense of being caught in the middle? Among the twenty library directors interviewed, sixteen reported that they most often feel caught between the demands of various user groups (faculty and students) seeking extended services and the fiscal requirements imposed by the school's administration. The major difficulty mentioned was the library director's lack of control over demands and resources originating outside the library. In order to perform efficiently, the library director must reach and maintain a balance between the demands made and resources available to meet those demands. Because the library directors must deal with people outside their usual base of power, their control is reduced.

Problems and conflicts magnified by the current fiscal crisis dominated the interviews: "The budget affects everything. . . . Almost all our problems center around finances." Because of the current fiscal crisis, the library directors are not always completely successful in their efforts to win what they consider ample support for the library.

Although the library directors recognize that such failures are not entirely their fault, most do feel the responsibility and know that others, in some part, place the responsibility on them: "Now you can just throw up your hands and say, 'It's all the legislature's fault.' But you know you can only do that once." 


\section{ADMINISTRATIVE INSTABILITY}

A particularly upsetting aspect of this problem seems to be the reported instability of the school administration, both in the person holding the office and in the particular office to which the library director reports.

One library director interviewed reports to a vice-chancellor of academic affairs. Since he became the library director in 1967, there have been six different men in this position-six different bosses to adjust to in nine years. Another library director reports to the dean of the graduate school. In six years he has gone full cycle, having started with the dean of the graduate school, then for a while reporting to the president (but he was too busy), then to the dean of the faculty (also too inaccessible), and now back to the dean of the graduate school (a different incumbent than before). This library director referred to these developments as a "revolving, I mean evolving" situation. Perhaps his initial thought, before the correction, best describes this not uncommon circumstance.

In its report Governance of Higher Education, the Carnegie Commission of Higher Education noted this problem. The commission warned about administrative instability, with focus on the position of president: "The actual tenure of presidents is about six years, half of what it once was." 6 This present examination of the second level of authority indicates that this administrative mobility continues to be a sometimes critical problem. To the obvious and felt detriment of library-administration relations, the actual tenure of academic vice-presidents and deans of academic affairs seems to be shrinking.

Basic to this situation of instability is a change in the way library directors distribute their time. Each shift in administrative personnel affects the library director, creating new demands on his or her time. Many of the directors interviewed felt that a disproportionate amount of their time must be devoted to educating the administration, to articulating and interpreting library matters to their newly installed superiors. "With each new provost I have to rebuild my power base. I depend on his backing particularly for fiscal matters. So the first step is in winning him over." Although they would like to be involved in other "now neglected" activities such as collection development, the current instability, coupled with fiscal difficulties of higher education, keeps their attention focused outside the library, focused on "developing a working relationship with the administration."

\section{External Focus}

Most library directors felt that the person to whom they are immediately responsible was very important in determining the library's budget. They also felt that because this person is outside the library-that is, outside the library director's direct authority-much of their influence must be through informal channels. The library directors reported that they relied heavily on the trust and working friendship of their immediate superiors: "When I need personnel, I rely on his help." The library director depends on this person for aid in obtaining proper financial backing. Thus, this instability of the school's administration is particularly disruptive for the library. This area of informal personal relations is seriously limited by the frequent changes in administrative personnel.

Another factor contributing to this outward focus is the current proliferation of the committee system, from search committees (directly related to administrative instability) to every variety of campus-wide committee, each with an important mission related to the school's goals and each calling for the time and energy of the library director. 
In these nonlibrary campus activities, while there is little consistency or homogeneity of type, there is certainly volume. Most of the library directors interviewed acknowledged the importance of their role as ambassador for the library and likewise participated in a variety of campus activities. Library committees (100 percent) and curriculum committees ( 80 percent) provided a common core, while the more peripheral activities showed far less consistency, including personnel committee, quality of student life committee, educational policies committee, various ad hoc committees, etc.

While very much pleased that they are included (having fought to get on in the first place), many library directors now view these ever-increasing demands on their time as a "mixed blessing." Some feel that they are walking a thin line between the external demands of their positions and the in-house needs of their personnel. For while the library staff is usually "sympathetic" to the librarian's out-of-house and off-campus responsibilities, they also "feel the need to have the director around." Time here seems to be at stake, with everyone demanding a piece of the director.

\section{UNIONIZATION}

Another factor which has modified the role of the academic library director is the introduction of collective bargaining (65 percent of the campuses visited were unionized). Many library directors reported experiencing the negative effects of union-management conflict. Some library directors feel that they have been "shunted aside as adversaries" in the process of collective bargaining. Technically these library directors feel they had to officially voice the administration's point of view. They are considered management, while their staff and the faculty are labor.

As management they are expected to play a particular kind of role. But several library directors admitted that privately their loyalties remain with the faculty and staff. Because of these changes in their role the library directors are denied the opportunity to fight for benefits for "their people." Before, a large part of the director's job was looking after the staff, but now the director no longer has the "satisfaction" of improving the situation for the staff. Collective bargaining has changed the director's role, creating a "them and us" attitude.

The directors expressed concern that their in-house power is decreasing rapidly, making effective leadership more difficult. Traditionally, if one individual librarian or group of librarians had a grievance, it would be discussed with the director. The director would either resolve the problem or make a request to an immediate superior. With collective bargaining this is no longer the case. Increasingly, staff who have grievances communicate directly with the grievance committee which then communicates with the board of trustees or the president. Thus the library director who formerly had control over some areas now finds staff negotiating directly with higher officials.

A small number of library directors reported being ineligible for faculty committees. Considered part of the administration rather than the faculty, they were kept from serving on committees whose membership was elected from the faculty. The three librarians who reported these conditions felt strongly that this hindered them in their jobs: "Communication is very difficult and chaotic in a way. Sometimes we find out about new programs after the fact." One librarian reported that for the first time his recommendations regarding promotion of a member of the library staff had been "overruled" by the faculty personnel committee, greatly diminishing his influence with his staff. 
Related to this issue of unionization is the conflict situation that accompanies the achievement of faculty status by the professional library staff. Expectations start to change, putting the library director again in the middle. The directors must defend librarians as equal to the faculty at the same time that they try to encourage the staff to be "something more than the traditional librarian." At the same time the library directors are expected to defend the librarian's parity with the faculty, they are excluded from participation in establishing criteria for evaluation.

\section{Personal Dimension}

There is a reported power realignment taking place in the governance of academic libraries, which has placed some library directors in a conflict situation. The library director depends on good relations with the administration to insure adequate support for the library yet must also deal effectively with the staff on a day-to-day basis. Faced with a loss of formal power, many library directors report depending much more on the personal dimension. To retain their influence, they rely on their personal authority and good "in-house public relations."

In those libraries where the directors felt they had succeeded in developing a close working relationship with their immediate superiors, the library directors also reported feeling that they had a reasonable amount of influence on fiscal decisions. In sharp contrast to this, those librarians who did not feel that they worked closely with the administration seemed much more fatalistic in the area of financial control.

Representative of this small minority, one librarian reported communicating with his dean "infrequently": "Every now and again I make an appointment with him to tell him how things are going, out of courtesy." This librarian did not express much confidence and trust in the dean's concern and cooperation. He also felt that his own input regarding fiscal decisions was "fairly minimal": "The administration accepts an annual expenditure as good and necessary. I always ask for more than I need because they always cut it. The budget is really an administrative thing ... we are told how much money we will have."

Another point of difference between these two types was the degree of tension reported. Academic library directors, facing constant demands from outside the library, reported experiencing this conflict with varying degrees of tension. Some seem well chosen and well equipped to handle the conflicts they face. Others seem much more vulnerable.

One variable, of course, is experience -the development of techniques for coping through years of experience with similar conflicts. But, in addition, the interviews conducted for this study suggest that one of the qualities required to cope effectively with stresses of the library director's role is self-confidence.

Librarians with strong professional identities, independent of their particular position, seem much less vulnerable to stress, much less prone to withdrawal and associated feelings of futility. They generally are satisfied with their performance, do not look to others to know what is expected of them, and possess a sense of effectiveness as active agents. They have frequent communication outside the library, and, although they report experiencing stress regularly, they do not report being upset by this conflict.

The most important sources of motivation for role performance are selfgenerated. These individuals have a conception of their offices and a set of attributes and beliefs about what they could and should not do while in this position. They seem to have strong occupational self-identities and to be moti- 
vated to behave in ways that affirm and enhance the valued attributes of that identity.

Again in contrast, this study found a small minority of library directors who reported feeling insecure and uncertain, who were unsure as to where they stood, and expressed feelings of isolation. These librarians expressed doubts about how others evaluate them and about how satisfied others are with their performance: "No one pays any attention to what I am doing . . . no formal evaluation . . . makes me feel uneasy ... I'd be much more comfortable if I got some response." Their communications outside the library are limited, and their sense of effectiveness is curtailed seriously. These librarians expressed dissatisfaction with their professional training and discomfort with the current lack of formal evaluative procedures.

Thus the stresses of these problems do not appear to be equally damaging to all who experience them. Some library directors respond to these conflicts in an aggressive, dynamic manner. They devote a great deal of time and attention to developing effective interpersonal bonds with their superiors and with their staffs. These library directors report a sense of satisfaction and effectiveness in their work. A small minority withdraw from problematic situations. Their psychological and behavioral withdrawal is reflected in a weakening of affective interpersonal bonds and an accompanying sense of powerlessness. For these, communication is infrequent, tension is high.

Of course; the problem inherent in this type of avoidance response is that low or infrequent communication risks neglect and is, therefore, likely to prove self-defeating. As one library director put it, "libraries are no one's bread-andbutter issue." In today's financial crisis, when the administration "has so many other problems that it is a relief for them not to hear from the library," the library director who loses visibility and who allows other matters to monopolize the attention of the top administrators also risks losing the power to assure adequate resources.

All twenty library directors interviewed reported being active professionally. Most often mentioned was "participation in professional organizations" (95 percent), followed by writing and consulting, with research lagging far behind. Twenty percent of the directors are members of the board of trustees of their local public library, and 10 percent teach courses at nearby library schools.

Most of the library directors emphasized their personal initiative-"I do these things of my own accord, through my concept of a professional"-and played down any college or university pressures: "If you asked them they would say yes, but in practice if I went home and did nothing my position would not be jeopardized." Yet it was clear throughout the interviews that these were all serious career people who were motivated by more than "what you have to do to stay." The majority of the library directors covered in this study knew what they should do to get ahead and they were doing it. No one needed to remind them.

\section{SUMMARY}

This study suggests that influence in colleges and universities on the library is not a zero-sum variable. That is, because one group has more influence, it has not followed that another group has less. There was a reported general tendency to believe that the power of most of the significant groups (students, faculty, administration, staff, and boards of trustees) had risen. For these twenty library directors there is apparently a sense that most offices or groups actually had increased in absolute influence. All reported active library committees, con- 
sisting of faculty, students, and in some cases members of the boards of trustees. Most reported some move in the direction of more staff participation.

But much of the urgency of the late 1960 s has subsided. The influence of such groups now tends to be strictly advisory. Students are more quiet and faculty members seem tired of campus controversy. Most importantly, financial stringency has almost forced the administration to play a more central role. In this study, then, the person perceived by our respondents as being the most important to their jobs is their immediate superior and is perhaps the single person whose decisions carry most weight in finances. Sharing directly in the power assigned to the president, this individual often acts as the "inside president" with respect to library matters.

Lacking any structured or formalized power over this superior, the library directors have a reduced ability to guarantee that the performance of this individual will be as they need and wish. So in compensation for this lack of formal authority, the library directors rely heavily on the affective bonds of trust, respect, and liking which they can generate. But due to an increased instability of administration, these bonds are unusually hard to create and maintain. The difficulties of library directors in such a situation are intensified. The deleterious effects of this instability seem most severe in fiscal matters.

In "The Library Administrator as Negotiator: Exit the 'Boss,'” Kenneth R. Shaffer points out that "the day of the managerial autocrat or figurehead content to delegate both his responsibility and problems to others is over ... and any administrator who expects to hold on to his job very long must be acutely conscious every moment of his working day of the ambivalent attitudes toward his authority on the part of his staff, his superiors, and outsiders."

It is hoped that this study may facilitate a better understanding of the nature and actual role of the academic library director, thus assisting in providing more effective library administration and better education for administration. It is hoped, too, that it will provide a base and indicate a direction for the more substantial studies that this problem demands.

\section{REFERENCES}

1. Ralph E. Ellsworth, "The University in Violent Transition," University of Tennessee Library Lectures, no.13-15 (1961-63), p.21.

2. Arthur M. McAnally and Robert Downs, "The Changing Role of Directors of University Libraries," College d Research Libraries 34:103-25 (March 1973).

3. Roger Horn, "The Idea of Academic Library Management," College b Research Libraries 36:464-72 (November 1975).

4. James Thompson, An Introduction to University Library Administration (Hamden,
Conn.: Linnet Books, 1974), p.34.

5. Robert L. Kahn, Organizational Stress: Studies in Role Conflict and Ambiguity (New York: Wiley, 1964).

6. Carnegie Commission on Higher Education, Governance of Higher Education: Six Priorities. (New York: McGraw-Hill, 1973), p.37.

7. Kenneth R. Shaffer, "The Library Administrator as Negotiator: Exit the 'Boss,'” $\mathrm{Li}$ brary Journal 100:1475-80 (Sept. 1, 1975). 